\title{
Cornelia Rémi
}

\section{From Green Gables to Grönkulla The Metamorphoses of Lucy Maud Montgomery's Anne of Green Gables in its Various Swedish Translations}

\begin{abstract}
This paper examines Swedish translations of Lucy Maud Montgomery's Anne of Green Gables (1908), a novel that has maintained the status of a children's classic in the Scandinavian countries for more than a century. I explore the background conditions of this long-lasting reception by analyzing significant differences between source and target text within this series of translations. All the translations have been adapted to the context of their target culture in general and shaped to address an audience of young female readers in particular. Many of the interventions correspond to general patterns in translations for children and reflect contemporary assumptions about the needs of young readers: they emphasize domestication over foreignization and add clarifying comments and explanations to cultural elements unfamiliar to a Swedish audience. Some minor inconsistencies point to turbulences within the translation process and highlight the low esteem for children's fiction within the literary system. Other, more consistent changes can be attributed to programmatic decisions that affect the very premises of Anne of Green Gables. The handling of intertextual references and some major abridgements reveal a tendency to disambiguate the protagonist's cross-over status between girlhood and adulthood, and clarify her often blurry position between the realms of imagination and reality. This results in the seemingly paradoxical result that the success of Anne of Green Gables in Sweden is founded on decisions that have narrowed down its literary scope.
\end{abstract}

Keywords: translation, translation studies, adaptation, abridgement, transcultural exchange, poetics, intertextuality, gender roles, girls' fiction, L.M. Montgomery, Anne of Green Gables

\footnotetext{
(C2019 Cornelia Rémi. This is an Open Access article distributed under the terms of the Creative Commons Attribution-Noncommercial 3.0 Unported License (http://creativecommons.org/ licenses/by-nc/3.0/), permitting all non-commercial use, distribution, and reproduction in any medium, provided the original work is properly cited.

Citation: Barnboken - tidskrift för barnlitteraturforskning/Journal of Children's Literature Research, Vol. 42, 2019 http://dx.doi.org/10.14811/clr.v42i0.447
} 
The reception of Lucy Maud Montgomery's Anne of Green Gables (1908) in Sweden can be described as a long love story. ${ }^{1}$ Swedish was the very first language into which Montgomery's novel was translated; the translation was published as early as 1909, only one year after the first edition. Ever since then, it has found passionate and devoted readers all over the country and gained the canonical status of a classic. The impressive speed of Anne's transatlantic import must be attributed to a series of fortunate events, quick reactions and personal commitment, on the part of publisher Agne Gleerup as well as on that of Seved Ribbing, professor of pediatrics, president of Lund University and member of the board of C.W.K. Gleerup's publishing house - and Karin Lidforss Jensen, an established translator of mostly popular fiction. Åsa Warnqvist has shed light on some important details behind the genesis of Jensen's translation by studying documents from the archives of the publishing house as well as from Ribbing's personal archive (Warnqvist, "Don't be too upset"; "I experienced a light" 229-233; “Anne på Grönkulla" 213-214): Ribbing brought the book to Gleerup's attention and recommended buying it for the Swedish market. One important argument for both men might have been that the novel echoes key topics from the backlist of the publishing houses, which specialized in non-fiction books on education and religious topics. The publisher ordered a sample copy from the British publisher in March 1909 and introduced Jensen to the book in late June, still without a confirmation regarding the official rights for translating Anne of Green Gables into Swedish. Jensen worked quickly and competently, so that she finished her translation by October and her text could be published before Christmas. Many voices have testified to how deeply Anne Shirley has etched herself into Sweden's literary memory since then (Warnqvist, Besläktade själar; "I experienced a light"), most prominently celebrated author Astrid Lindgren, whose own books illustrate the inspiring influence of Montgomery's heritage on several generations of Swedish readers and writers (Åhmansson 14; Death; Rémi; Warnqvist, "Under körsbärsträdet" $){ }^{2}$

But this influence has been taking detours since its very beginning, for naturally Anne of Green Gables did not conquer Sweden in its original wording, but transformed into the Swedish guise chosen by Karin Jensen and other translators. While previous studies have only mentioned a few characteristics of what is commonly considered the Swedish standard text, namely Jensen's translation (Åhmansson 18-19), I aim to analyse the differences between the English source text and its counterparts more systematically, taking into account all Swedish translations that have been published so far. ${ }^{3}$ Starting with 
single terms and expressions I will move on to larger chunks of text, with a focus on particularly notable changes that have shaped Anne's distinct profile in Sweden. My observations will link these transformations to various categories of influences affecting the translation process. I will also highlight how narrowing down the message of the novel in the translation has sacrificed a substantial share of its characteristic openness, but thereby also stabilized its key message in a way that offered decisive points of contact for later literary developments and granted its enduring allure for several generations of Swedish readers. This poses the question whether the reduced, but thus sharpened character of Anne has become essential to the novel's status as a literary classic, or whether the future reception of Anne of Green Gables in Sweden might benefit from a revised translation that reintroduces some of the hitherto lost qualities of the source text.

\section{Translations for Young Readers: Transfer and Transformation}

Like any text crossing over into other languages and cultures, Anne of Green Gables has morphed into different guises and changed, sometimes considerably, in its international translations (Gammel et al.; Szymańska; Seifert 333-337; Allard 350-356; McKenzie). No translation creates a text clone that remains entirely identical to its source (Oittinen 76-84). Translating a novel always means transforming it as well, be it to accommodate different language structures, or to fix references, if the source text mentions an item that either does not exist in the target culture or is assigned a different value there, so that translating a reference to this concept literally would lead to misunderstandings and confusion for readers in the target culture (Aixelá 57; Nikolajeva, Children's Literature 30). While this means that translators not only mediate between languages, but between cultures as well (Bassnett, House), there exists no simple rule for deciding how to handle such culture-specific items: conserve them, delete them, explain them in added comments, or replace them with something else (Aixelá 61-65; Lathey, Translating 53)?

The question whether and how to translate culture-specific concepts is a shibboleth of translation fundamentals that points to an eternal dilemma facing translators. Are they to remain as close to the source text as possible ("true to the text")? Or should they deviate from the source and try to recreate the communication scenario surrounding it, enabling the target-culture readers to get as close to the original reading experience as possible ("true to the reader," cf. Nikolajeva, "Translations" 407-408; Schleiermacher 74)? Regarding culture-specific concepts, this turns into a decision whether to con- 
front readers in the target culture with foreign elements (foreignization) or whether to tone down and minimize them (domestication).

Translations of children's literature show a general preference for the latter strategy, even when they strive to preserve the atmosphere of the source culture (Bell; Davies; Brewster; Lathey, "The Travels of Harry"). They also feature traces of many other accommodating interventions that may even turn them into adaptations. These tend to reduce the text's level of complexity and might range from stylistic modernization, simplification or changes of register to outright omissions or additions, which can affect characterizations or plotlines (Garavini; Shavit, Poetics 171-177).

Research on translations of books for young readers has frequently stressed some common factors that make these texts susceptible to more comprehensive changes than other areas of literature $\left(\mathrm{O}^{\prime}\right.$ Sullivan, Kinderliterarische Komparatistik 172-240; O'Sullivan, "Children's Literature"; Lathey, "The Translation of Literature for Children"; Nikolajeva, "Translations"; Tabbert). These factors are rooted in the peculiar conditions for the production, distribution, and reception of children's literature within the literary system (Shavit, Poetics 63; Nikolajeva, "Translations" 405). Firstly, children's literature is considered a marginalized literary subsystem of rather low status, so that its texts are lacking the dignity and ensuing stability of high-status texts (Surmatz 23-28; Tabbert 312-315; Shavit, "Translation" 171). Secondly, many critics treat them less as works of art than as functional texts serving specific purposes, since they consider them to belong not only to the realm of literature, but to the educational system as well. Therefore we can judge them based on two often conflicting sets of norms and principles, on their artistic as well as their educational merits. A third component is enhancing these interferences: It is adult gatekeepers and mediators who control young readers' access to literature and determine the contents of their reading matter in accordance with the norms and values of their contemporary society and their resulting concepts of childhood (Ewers 9-15). Texts for young readers need to address these adult stakeholders as well and cater to their notions and assumptions about what is good and suitable literature for children, adequate to their level of knowledge and appropriate for their cognitive, emotional, and moral development (Nikolajeva, "Translations" 408-409; Stolt 72-75).

These background conditions reinforce the general dilemma of translators, who need to calibrate their approach between orientation towards their source text and the target culture of their translations. While some studies stress the literary dignity of the source text and the importance of confronting children with foreign elements 
(Klingberg), the opposite strategy is more common. Therefore translators, publishers, and editors frequently simplify translated texts for young audiences and adjust them to their assumed needs (Surmatz 28-32; Tabbert 337-340; Shavit, "Translation" 176-177; ThomsonWohlgemuth 230-231). Diligent scholarly analysis should strive to do justice both to the target and the source text and try to understand the guiding principles behind such changes (Surmatz 36). In the case of Anne of Green Gables, this approach helps to grasp the response the novel met in Sweden, and to realize what its publishers considered the essential characteristics of Montgomery's text.

During the course of the $20^{\text {th }}$ century, the Swedish pedigree of Anne of Green Gables has sprouted an impressive amount of different editions: Of the three existing translations (1909, 1941, 1962), Karin Jensen's remains the most persistent and influential one. Although many Swedes have excellent English language skills, young readers' first encounter with Anne will still be in this Swedish guise, unless it is mediated by the TV adaptations. My analysis will therefore focus on Jensen's classical text and be complemented by a brief overview of the other Swedish versions. In certain regards these versions differ so much from their source text and from each other that one might wonder if the resulting books are actually telling entirely different stories.

\section{Intercultural Approaches: Place Names and Food}

Translatory choices affecting single terms are often more obvious than more extensive changes on higher levels of the textual hierarchy. In a novel like Anne of Green Gables they are important nonetheless. Given the protagonist's passion for the beauty of language, even a single word may contribute substantially to the atmosphere of the narrative. Names are a particularly relevant class of words in this context, since they can be packed with information that adds to their bearer's or giver's characterization and alludes to a dense fabric of cultural contexts. Therefore many scholars studying translations for children have discussed how to deal with expressive names (Epstein, Translating 67-98; Lathey, Translating 37-49; Bertills 40-56; van Coillie 124; Klingberg 30-53; Fernandes; Nord). Confronted with a name, the translator faces the choice of either preserving it, finding an equivalent, paraphrasing it, explaining it or omitting it entirely (Epstein, “In Name Only?" 197; Epstein, Translating 75; van Coillie 124-129).

One group of such terms are place names, which help readers to orient themselves and to locate events in a specific geographical location. For foreign readers they also mark the distance between the story's setting and their own homeland. Jensen strives to reduce this 
impression of distance by either eliminating place names, especially at the beginning, or by translating and thus domesticating them. Therefore Green Gables turns into "Grönkulla" (literally "green hill," also "frog orchid") and Orchard Slope into "Tallbacken" ("pine hill"), while White Sands and the Gulf of St. Lawrence are assigned literal Swedish translations. Other place names, however, remain completely unchanged, like Newbridge, Bright River or Carmody, and thereby preserve a hint of distance and strangeness. This results in a patchwork geography, which marks the landscape as a poetic construction located in an interspace between the Canadian Maritimes and Sweden. The resulting ambiguity opens up the novel's poetic space both for readers eager to explore exotic new worlds and for those looking for familiar surroundings. Other elements also leave the question of geographic distance undecided: On one hand, Jensen (97) adds familiar Swedish plants to the Barry family's garden and weeds out some American ones (74-75), on the other hand, she preserves the original personal names, an amusingly irritating trait for generations of Swedish readers struggling to fit the foreign spelling into their frame of familiar pronunciation rules (Warnqvist, Besläktade själar 57, 61, 77, 80-81, 269).

The translator must also tackle the name creations which Anne herself bestows upon her most beloved places. Two of these are especially interesting: They grant deeper insights into the translation process, since Jensen renders them rather inconsistently: When Anne first introduces her name for the spring by the log bridge, "the Dryad's Bubble" (76), Jensen translates this as "Dryadens springbrunn" ("the Dryad's fountain," 99), ${ }^{4}$ and Anne's name for the little pool "Willowmere" (79) as "Klaröga" ("clear eye," 104). But when Anne later mentions these places again, they have suddenly changed their names: For the rest of the novel, whenever the Dryad's Bubble is mentioned (102, 110, 132, 140, 201, 232), it becomes "Skogsnymfens källa" ("the wood nymph's spring," 137, 149, 182, 191, 270, 314), while Willowmere $(88,89)$ turns into the somewhat bulky "Pil, pil, susa!" ("Willow, willow, sough!" 117, 118). This phrase is highly poetic, yet so vague that the reader is unable to determine whether it refers to a pond, a hill or a grove. ${ }^{5}$ Such inconsistencies suggest some sort of disturbance in the translation process. They might indicate time pressure, an interruption of Jensen's work or the involvement of an unknown collaborator, who substituted her terms with others and either missed their first mention or didn't bother to work their way through the entire manuscript. The resulting discrepancies remain invisible to a reader who is not familiar with the English text. Since they increase the stock of Anne's inventions, they actually strengthen 
her profile as a poet and dreamer, but also weaken the spatial coherence of her world.

The translator's strategy becomes clearer when she touches the denser cultural context of food preparation and consumption - key elements for establishing a sense of cultural identity in many texts, and hence a frequently discussed challenge in translation studies as well (Chiaro and Rossato; Bar-Hillel; Klingberg 36-38). In Anne of Green Gables this is a key area for Anne's development. Since cooking requires a discipline that she finds difficult to master (104), this prompts her to choose her own, unorthodox domestic path in the kitchen as well as beyond it (Salah). Jensen responds to the challenge of translating food terms by amplifying Montgomery's original menu and adding a decidedly Swedish taste to it. When, for example, Marilla is about to leave for White Sands with Anne, she informs Matthew about the preparations she intends to make for his afternoon tea (36). Jensen adapts this announcement to Swedish eating habits (41):

I'll set your tea out for you and I'll be home in time to milk the cows.
Jag sätter in kaffepannan i stekugnen, och pepparkakor har jag lagt upp på gröna tefatet. Jag kommer hem tids nog för att mjölka korna.

(I will put the coffee pot into the oven, and I have laid some gingerbread on the green saucer. I'll be home in time for milking the cows.)

Coffee is actually never mentioned in Montgomery's entire novel; but a Swedish farmer was far more likely to refresh himself with a cup of coffee than with tea in Jensen's time (Åhmansson 18; Klingberg 37). She also added biscuits to the scene to illustrate that a tea break in the Canadian sense would include some sort of snack. Therefore her amplification serves as an annotation that has been merged into a character's speech. Naturally, not even Anne herself drinks tea on her first morning at Green Gables, like in Montgomery's text (33-34). Instead she has a cup of coffee and even dunks some "rågskorpor" in it (38) - a sort of rye rusk that Anne's Swedish contemporaries would have regarded as a typical breakfast ingredient. The translator's reasoning here appears to be that the girl does not actually have breakfast unless her meal is described in more detail.

However, Jensen also adds information and explanations that are not so easily motivated by an intention of bridging cultural gaps. These point to other, often educational considerations affecting 
her choices and reveal the distinct presence of a translator's voice, which allows conclusions about the implied audience and hence the address of the translated text (O'Sullivan, "Narratology" 202-205; Kinderliterarische Komparatistik 141-274). Some of the amplifications just add some colour to the scene and might satisfy the curiosity of inquisitive readers. After the concert at the White Sands Hotel, for example, Montgomery merely sketches the surroundings without too much detail: "They had supper in the big, beautifully decorated dining room" (218). Jensen, on the other hand, enhances the grandeur of the scene by inserting the detailed order of the menu into this sentence: "De superade inne i den vackra, festligt dekorerade matsalen - hummer, fågel och glass!" ("They had supper in the beautiful, festively decorated dining hall - lobster, poultry, and ice cream!" 293). While this description merely expands the account of the source text, another culinary supplement not only ties the scene more closely to its Swedish target culture, but also offers a little background story that can be read as an instruction for recreating the food presented here. When Anne prepares a layer cake for Mrs. Allan (142), Swedish readers receive a far more tangible image of that cake, because Jensen transforms it into the familiar shape of a "piggsvinstårta" ("porcupine cake"), decorated with almond spines - she even describes its preparation (193).

\section{An Educational Voice}

Some of Jensen's added comments appear almost patronizing towards her Swedish audience, suggesting that she constructs readers who need or want to find out more about particular domestic skills. Just like with the cake recipe, she seems to assume that her Swedish readers desire or require additional information when any kind of needlework is mentioned. Since both areas are usually associated with female expertise, it seems these amplifications address a young female audience. Clothes and fabrics are frequently described in far more detail than in the source text, ${ }^{6}$ and when Diana teaches Anne a new crochet stitch (121), Jensen adds a detailed description of that stitch, which lets the readers in on the secret and thus includes them in the friendship of the two girls (166-167).

Other passages, however, reveal a more hierarchically structured didactic impetus behind some of Jensen's inserts. They resemble the utterances of a teacher and confirm the pedagogic authority of the translator's voice. Amongst other things, the Swedish text expands the description of a daring game to deter the readers from similar behaviour. When Charlie Sloane dares Arty Gillis to jump over a 
well (132), the Swedish narrator hastens to add that "he wet one of his trouser legs" in the jump ("han blötte ned sitt ena byxben," 183). This added comment pictures the negative consequences of an unwise action and turns the playful episode into a mild cautionary tale. Even positive utterances, however, cannot always deny their didactic motivation. While the original Diana simply announces that she intends to braid Anne's hair before the hotel concert (213), her Swedish counterpart adds a more detailed, almost pedantic explanation of a necessary step prior to the actual hairdressing: "Jag kammar dig sedan, när vi dragit kjolen över huvudet på dig; jag ska fläta ditt hår" " II will comb you later, after we have pulled the skirt over your head; I am going to braid your hair," 287).

In such passages, Jensen's translation starts tilting over into a free adaptation; she even changes the menu of the dinner Mrs. Barry prepares in Anne's honour. When Anne describes this meal, she mentions "fruit-cake and pound-cake and doughnuts and two kinds of preserves" (121-122). Jensen probably felt that this menu was lacking some substance for a supper on a winter evening and therefore offers a replenished selection of food: "skinn- och benfri anjovis och hårdkokta ägg och pepparkakor och gorån med två slags sylt till" ("skin- and boneless anchovies and hard-boiled eggs and biscuits and crisp wafers with two kinds of marmalade," 167).

Here and in many similar cases Jensen has positively rewritten parts of Montgomery's text. While some of these changes may be justified, for example because they deliver necessary explanations or compensate for information that she had previously omitted, there is often no apparent motivation for them. Why does the dress that Matthew gives Anne for Christmas (160) change colour and turn moss-green instead of remaining brown (217)? Why is superintendent Bell equipped with grey sideburns in the Swedish text (209) instead of whiskers (153)? It seems that the momentum of Anne's imagination has swept her translator away and inveigled Jensen to join her heroine in utilising her creative scope and inventiveness, often with the purpose of either making the text more accessible and comprehensible to contemporary Swedish readers or of clarifying an educational message.

This didactic impetus might also be the driving force behind Jensen's attempts to introduce additional humorous elements to some scenes, often at Anne's expense. Their high frequency suggests that Jensen considered them important - so important, in fact, that it does not seem to matter whether they result in contradictions and inconsistencies. When for example Anne and Diana jump on Aunt Josephine Barry, Jensen is not content with the information that "so- 
mething" is moving beneath the girls (127) - to enhance the burlesque character of the scene, that something must be "something quite large and fat" ("någonting rätt stort och tjockt," 175). Later on, however, when Montgomey describes Josephine Barry as "thin, prim and rigid" (129), Jensen translates this quite literally as "mager, stel och siratlig" ("thin, stiff and stately," 179), so that Aunt Josephine seems to change from one body shape to another, completely different one. Sloppiness and time pressure might account for this contradiction, but what matters more is the tendency to ridicule Anne's unconventional behaviour and thus discourage readers from imitating it. Other amplifications appear even more openly sneering and therefore disloyal towards Anne's character. When Marilla for example finally allows the orphan girl to attend the Sunday school picnic, Anne reacts with frantic fervour. Jensen, though, interrupts her jubilant speech with a burlesque parenthesis that sabotages her pathos and thus anchors her in reality:

"Oh Marilla," exclaimed Anne, flying to the wash stand. "Five minutes ago I was so miserable I was wishing I'd never been born and now I wouldn't change places with an angel!" (87)
O, Marilla, utbrast Anne och störtade sig på huvudet $\mathrm{i}$ tvättfatet. Efter några sekunder: För fem minuter sedan var jag - m-m-m, där fick jag tvål i ögonen, usch - var jag så gränslöst olycklig, att jag önskade att jag aldrig varit född, och nu skulle jag inte vilja byta med en ängel.

(“O, Marilla, Anne blurted out and hurled herself head first into the washbowl. Some seconds later: - Five minutes ago I was m-m-m, now I got soap in my eyes, bah - I was so infinitely unhappy, that I wished I had never been born, and now I would not change with an angel," 115-116)

While such additions might appeal to younger readers' sense of humour (Warnqvist, Besläktade själar 88), they also appear condescending towards a character whose heartfelt despair and delight they ridicule and question. Once again these changes appear to sanction unconventional, wild or excessive behaviour and promote a more disciplined conduct instead.

The ridicule directed at Anne here has even graver consequences when her beloved and respected teacher Miss Stacy explicitly supports its underlying criticism in the Swedish text. When Anne is about to found the Story Club as a forum for cultivating her imagination, she recalls Miss Stacy's opinion on her phantasies about the Haunted Wood, which makes her question her imaginative app- 
roach a little: "I told her about the Haunted Wood, but she said we went the wrong way about it in that" (169). While Miss Stacy's judgement maintains a simple and sober tone in the source text, Jensen adds a remark that does not offer serious guidance, but rather mocks and taunts the girl: "Jag berättade för henne om spökskogen, och då sa' hon, att sådant var alls inte bra för - för - ja, jag vill minnas hon sa' hönshjärnor ..." ("I told her about the Haunted Wood, and she said that such a thing was not good at all for - for - yeah, I remember her saying chicken brains ...," 228-229). Such an utterance changes the profile of Miss Stacy, who despite all her serenity always takes her students seriously. In this case ideological consistency, namely a certain idea of proper behaviour and good manners, also affects the integrity of the original text and its characters.

\section{Limiting the Scope for Imagination}

Apart from such judgmental additions, Jensen has preserved the stylistic diversity of the novel rather well. But even small changes, barely noticeable on the level of single sentences or paragraphs, may have far-reaching consequences in relation to the text as a whole. Montgomery has equipped some of her central characters with signature phrases that are repeated over and over again in different situations, maybe as signs of their stereotypical behaviour patterns in contrast to Anne's lively, varied way of talking. These phrases are an essential part of the characters' voices, be it Marilla's "fiddlesticks" exclamations, Rachel's "that's what" or Matthew's "[w]ell now". But Jensen, who delivered her translation in batches rather than as an entire text (Warnqvist, "I experienced a light" 231; “Anne på Grönkulla" 214), appears to have either overlooked these distinctive speech mannerisms or considered them redundant, since she translates them inconsistently throughout the book, thereby forfeiting an important element of Montgomery's characterization.

Even Anne's own persistent and programmatic plea for some "scope for imagination" vanishes from the Swedish text: Jensen sometimes omits it entirely, sometimes paraphrases it or chooses varying phrases to replace it. ${ }^{7}$ This deprives the text of a connecting speech element that enriches the character of Anne with almost lyrical qualities, like the refrain in a song. We first encounter Anne's mental refrain and key phrase in the words of the station master at Bright River, who points Matthew to the lonely little girl waiting on the platform and quotes her reason for staying outside rather than expecting him in the waiting room: "'There was more scope for imagination,' she said" (15). While Montgomery's Anne refers 
to the force of her own creativity to motivate her decision, Jensen's translation emphasizes the perception of external stimuli rather than the imaginative processes inside Anne's mind: "Här hade hon - hur var det nu igen? - ett större fält för iakttagelser, sa' hon" ("Here she had - what was it now? - a bigger field for observations, she said," 12). Jensen then misses the opportunity to establish this as a characteristic stock phrase for Anne. The orphan girl mentions the "scope for imagination" twice in the excited stream of words bubbling out of her during her carriage ride to Green Gables, once to describe the desolation of the asylum ("But there is so little scope for the imagination in an asylum," 17), once to hail the creative force in not knowing things yet, prompted by Matthew Cuthbert's inability to explain the red colour of the roads (18-19): "Isn't it splendid to think of all the things there are to find out about? It just makes me feel glad to be alive - it's such an interesting world. It wouldn't be half so interesting if we knew all about everything, would it? There'd be no scope for imagination then, would there?" For the first mention, Jensen's translation only captures the negative aspects instead of the positive counter-concept that remains present in Anne's original negation: "Men allting är så förfärligt enahanda och alltid likt sig på ett barnhem" ("But everything is so awfully monotonous and always like itself at an orphanage," 15). For the second mention she entirely omits the decisive final question from the passage quoted above (17). She also skips (35) the next occurrence of the phrase, when Anne wakes up after a desperate first night at Green Gables and finds consolation in the view of the blooming cherry tree outside her window: "There was scope for imagination here" (31).

For most of the following passages, where Anne points to the rich, open playground for creativity that she discovers in the world surrounding her, Jensen chooses varying translations that tend to stress different mental powers than Montgomery, namely intellect and perception rather than imagination. For example, Anne praises the openness and seemingly infinite possibilities of mornings, still on her first morning at Green Gables: "All sorts of mornings are interesting, don't you think? You don't know what's going to happen through the day, and there's so much scope for imagination" (33). Jensen instead shifts the emphasis from Anne's creativity to her knowledge: "Jag tycker om alla slags morgnar - det är så roligt att tänka på, att man aldrig vet, vad som kan hända fram på dan ..." ("I like all kinds of mornings - it is so much fun to think that you never really know what might happen later in the day ...," 37). A similar shift occurs in the paragraph where Anne asks Rachel Lynde's permission to sit under the apple trees in her garden: "There is so much more 
scope for imagination out there" (65). Again, Jensen stresses Anne's intellectual powers and her perception rather than her imagination: "Därute har jag så mycket att titta och fundera på" ("I have so much to look at and think about out there," 84). Where Jensen preserves the source text's focus on imagination, she changes distinctive nuances of the creative activity that Anne advocates so vehemently. Take for example the paragraph where Anne describes to Marilla how she imagines herself to be the wind blowing around Green Gables: "Oh, there's so much scope for imagination in a wind!" (67). Here the translator chooses to let Anne assess the actions of the personified wind as entertaining instead of stressing its inspiring qualities for herself: "O, vad en vind kan hitta på mycket roligt!" ("Oh, how much fun a wind can come up with!" 87).

Particularly interesting are the passages where Anne in the source text denies the "scope for imagination" in certain activities, like patchwork sewing, cooking, or geometry $(79,104,114)$. In these cases Jensen tends to emphasize Anne's contempt of rules more than the limitations enforced upon her imagination, which makes her character appear somewhat more immature and inexperienced than in Montgomery's text, where the repeated key phrase links Anne's utterances back to her fundamental desire for freedom and creativity. Instead of pointing out to Marilla that "there's no scope for imagination in patchwork" (79), Jensen's Anne moans that "det här är så gruvligt enahanda" ("this is so horribly monotonous," 103). Similarly Anne complains to Diana that "[t]here's so little scope for imagination in cookery. You just have to go by rules" (104). Instead of translating the key phrase literally, Jensen repeats and expands the idea of being bound by rules, which again presents Anne as somewhat unwilling to learn these rules rather than stressing her lament for lacking creative opportunities: "Man är så bunden, när man ska laga mat, man måste noga gå efter reglerna i kokboken, och jag tycker bäst om att få fantisera på egen hand ..." (“One is so bound when one is to prepare food, one has to go precisely by the rules in the cookbook, and I prefer to be able to fantasize on my own," 140-141). Only once in the entire Swedish text does Jensen come up with a phrase that might serve as a general Swedish equivalent for Montgomery's "scope for imagination" - but, again, she limits the poetic power of her words by expanding the wording and pointing out Anne's childish contempt of rules. The context is Anne's complaint to Marilla about the newly introduced subject of geometry at school: "There is no scope for imagination in it at all" (114). Jensen's translation of this sentence shifts the focus from Anne's imagination to a question of learning discipline and thereby dampens the force 
and relevance of her words: "Jämt är man så bunden av dumma regler, och ens fantasi har inget spelrum." ("On is always so bound by stupid rules, and one's imagination has no scope for playing" 156). All these widely varying choices for translating the same English words demonstrate Jensen's own translatorial creativity. While one might partly explain them by tracing them back to disruptions in the translation process, it remains noticeable that Jensen so consistently avoids Anne's conspicuous key phrase and directs our attention away from her imagination towards other facets of her character: Anne appears childlike rather than entirely serious and justified in her judgement, focused on intellectual skills rather than creativity. And although Jensen still produces a richly nuanced text, the loss of a repetitive, connecting speech element also reduces the poetic qualities of the novel.

\section{Tectonic Changes: Shifts of Intertextual References and Allusions}

Another recurring element of the source text are literary allusions. Anne of Green Gables contains many poetic and lyrical passages that support Anne's imaginative vein. These elements do not serve as merely superficial stylistic devices, but are deeply rooted in the fundamental concepts of Montgomery's book. Her novel promotes the power and potential of imagination - manifest in poems, plays, and stories - as a tool for living a rich and meaningful life even under dismal conditions. Anne survives the ordeal of her childhood years in Nova Scotia by absorbing every bit of poetry she comes across. Both her speech and that of the narrator are therefore interspersed with poetic quotes and allusions (Wilmshurst; Doody and Barry; Doody Jones). The entire novel is drenched in intertextual references that illustrate how its main character immerses herself in the cosmos of poetry and fiction, just like the author who invented her (Karr 22-29; Woster).

The question of how to handle such intertextual phenomena is another hotspot of translation studies, since texts rich in intertextual references tend to be deeply embedded in the traditions and literary conventions of their source culture (Desmet; Lathey, Translating 50-53; Epstein, Translating 129-166). In the case of Anne of Green Gables these references, so central to the characterization of the novel's protagonist, also constitute a special challenge for Swedish translators, as most of the referenced texts do not belong to Sweden's literary canon. What to do with them? Replace them with quotes from known Swedish authors? Translate them as prose or as verses? Eliminate them? 
Jensen approaches this challenge in several different ways. Of the numerous allusions embedded in the text, only a few are still recognizable as such in her translation, and a good many of them have been omitted completely - among them the quote from Robert Browning's poem "Evelyn Hope" on the title page of Anne of Green Gables, which serves as an epigraph for the entire novel and for Anne's character: "The good stars met in your horoscope, / Made you of spirit, fire and dew" (Browning 174). Likewise disappeared (66) has a comment in which the narrator compares Marilla with a character from Lewis Carroll's Alice's Adventures in Wonderland to stress her adult authority: "Marilla was as fond of morals as the Duchess in Wonderland" (52). The remaining references often merge into the surrounding prose, and even if their lyrical tone is preserved, the loss of poetic substance is considerable, which weakens the bonds of Swedish Anne to the realm of poetry and anchors her more deeply in reality than her Canadian namesake.

Karin Jensen actually does try to find Swedish equivalents to the texts of Tennyson, Byron, Pope and others that Montgomery quotes, but comes up with alternatives in only a few cases. One prominent example is a poetic quote used by the narrator to comment on Anne's mood: After a disastrous tea invitation, which culminates in Anne unintentionally getting her friend Diana Barry drunk, Diana's mother forbids her ever to play with Anne again. When Anne, who has been studying at home for a while after an altercation with her teacher Mr. Phillips, returns to school the following Monday, the narrator describes her loneliness. Although the other girls welcome Anne back with small gestures of affection, she cannot enjoy this welcome, since her best friend must not speak to her. To illustrate how Diana's distanced demeanour affects Anne, Montgomery inserts two verses from Lord Byron's narrative poem Childe Harold's Pilgrimage ( $4^{\text {th }}$ Canto, stanza 59). The quote is from a longer meditation on the church of Santa Croce in Florence. Byron describes the great men buried inside it, but particularly highlights the absence of three others missing from this pantheon of famous Florentines: the great Renaissance poets Dante, Petrarch, and Boccaccio.

The quote that Montgomery has chosen to transfer into Anne of Green Gables makes a comparison to illustrate the feeling that the very absence of a beloved person stresses their importance: "The Caesar's pageant, shorn of Brutus' bust / Did but of Rome's best Son remind her more" (113; Byron 32). Jensen replaces the reference to Byron's Romantic classic with a shorter line by nineteenth-century poet Gunnar Wennerberg, taken from the $30^{\text {th }}$ song of his Gluntarne, a 
collection of musical conversations between two university students (153, Wennerberg 211). It is the last verse of the final song in the cycle, in which one of the two students is mourning the departure of the other: “Men - 'nämn en sällhet, som varar beständigt!' Den i ögonen fallande frånvaro av varje litet vänskapstecken från Diana Barry [...] blandade en smula malört i Annes lyckobägare” ("But - 'name a joy that lasts permanently!' The conspicuous absence of any small signal of friendship from Diana Barry mixed a little bitterness [literally: wormwood] into the chalice of Anne's joy," 153). Neither the Swedish nor the English quote is attributed to a character and must therefore be assigned to the voice of the narrator, who uses them to comment on Anne's thoughts and feelings. Although Anne is not aware of either quote, they frame the situation and influence how we perceive her emotions in this scene.

Both reference texts transport the notion of loss and absence, but are not entirely equivalent: The source text quotes two Byronic pentameters, the translation just one of Wennerberg's tetrameters and thus provides much less word material to link to the main narrative. Byron's verses evoke an entire situation, which could be read as an allegory of Anne's state of mind: a female character (the church of Santa Croce) is missing and longing for the inspiring presence of a great and noble person. That Montgomery suggests a Canadian schoolgirl to be the equivalent of Julius Caesar does not ridicule Anne or Diana in this case, but heightens and highlights the earnest intensity of their friendship. Byron's high, poetic style lends the scene additional gravitas in the source text and ennobles Anne's emotional condition. Wennerberg's line feels lighter and less concrete in comparison. It possesses the pointed quality of an adage, but does not evoke a scenic context, which is why Jensen adds a brief explanation to clarify the connection to Anne's situation. While she does phrase this comment in figurative language, she does not recreate Byron's high style and only focuses on the transience of Anne's joy, not on the quality of her friendship to Diana.

While the substance of both references points in a similar direction, the new allusion still alters the narrator's attitude towards Anne. Regardless of whether readers can identify the sources of the quoted verses and include their original context in their reading of this passage, Jensen's Swedish version appears dampened and more moderate in tone. While Byron's verses lend the scene poetic dignity, the Wennerberg reference appears at least toned down. One might even read it as an ironic comment on the girl's rapidly changing sentiments and therefore as a judgmental aside, which again would stress 
the gap between Anne's internal world and her external reality, and mark her feelings as somewhat exaggerated in the Swedish text.

In another case, Jensen does not come up with a Swedish alternative, but replaces Montgomery's original reference text, Walter Scott's epic poem Marmion, with one that was better known in Sweden. The scene is not unimportant, since it demonstrates Anne's devotion to poetry even during her daily chores and shows how her poetic perception heightens even the most mundane activities:

The cows swung placidly down the lane, and Anne followed them dreamily, repeating aloud the battle canto from "Marmion" - which had also been part of their English course the preceding winter and which Miss Stacy had made them learn off by heart - and exulting in its rushing lines and the clash of spears in its imagery. When she came to the lines:

"The stubborn spearsmen

still made good

Their dark impenetrable wood,"

she stopped in ecstasy to shut her eyes that she might the better fancy herself one of that heroic ring. (184-185)
Korna lunkade beskedligt utför stigen, och Anne följde dem, försjunken i tankar och läsande högt för sig själv ett stycke ur "Macbeth". De hade fått göra bekantskap med Shakespeare i skolan förra vintern, och den engelske skalden hade gjort ett mäktigt intryck på Anne, som lärt sig ganska mycket av skådespelen utantill. När hon kom till raderna:

$$
\begin{aligned}
& \text { "Frukta ej, } \\
& \text { Förr'n Birnams skog går fram mot } \\
& \text { Dunsinan." } \\
& \text { Nu går en skog ju fram mot Dunsinan, } \\
& \text { Upp upp, till vapen! }
\end{aligned}
$$

slöt hon hänförd ögonen för att bättre kunna föreställa sig den framryckande krigarskaran med de gröna grenarna $i$ händerna

("The cows were meekly trotting down the lane, and Anne was following them, absorbed in her thoughts, and reciting a passage from 'Macbeth' for herself. They had become acquainted with Shakespeare at school the previous winter, and the English poet had made a powerful impression on Anne, who had learned many passages of his plays by heart. When she reached the lines: 'Feare not, till

Birnam Wood / Do come to Dunsinane, and now a Wood / Comes toward Dunsinane. Arme, Arme, and out' [Macbeth V,5] she closed her eyes enrapturedly that she might the better imagine the advancing crowd of warriors with the green branches in their hands," 248) 
Jensen not only changes the reference text, but also Anne's motivation for learning it by heart: For Montgomery's Anne, this has been part of her homework, while Jensen's Anne voluntarily chooses to learn passages from Shakespeare's plays and proves herself to be a student working beyond her duties. However, she does not go so far as to include herself in the fictional army she evokes. The replacement seems to work altogether fairly well: Both quotes mention a band of warriors marching through a wood and create an image of martial heroism to which Anne's own idyllic and peaceful occupation forms a slightly comic, but also heart-warming counterpart. The Swedish Shakespeare reference even ties in with a previous mention of Macbeth, because Jensen has Anne recite "Lady Macbeth" (211) instead of Henry Glassford Bell's "Mary, Queen of Scots" at school (154). This change and the later substitution of Macbeth for Marmion constitute a web of plausible equivalents to the source text. However, Jensen's choice not to have Anne imagine herself among the warriors clearly deviates from this strategy and appears to be motivated by contemporary gender concepts and notions of decent female manners.

Notions of gender- and age-appropriate behaviour also might motivate a couple of other interventions. These changes alter Anne's profile as a reader and thereby transform her character as well. In the English source text, she reluctantly confesses to Marilla that Miss Stacy has caught her reading Lew Wallace's Ben-Hur at school. She admits that she has been so fascinated by the climactic chariot race that she continued reading it even while she was supposed to study (193). Jensen replaces the hidden book in Anne's lap with Harriet Beecher Stowe's Uncle Tom's Cabin and the chariot race with "den där lilla lustiga negerflickan Topsy" ("that little funny negro girl Topsy", 260). Since Ben-Hur certainly was no unknown entity in Sweden in the year 1909 - A. Boggiano's translation was published as early as 1888 by Skoglund's publishing house in Stockholm - there is no obvious reason why Anne should not read Lew Wallace's novel, a nineteenth-century bestseller about a young Jewish nobleman's path from vengeance to redemption and conversion. But despite its Christian core message, quite a few of the more brutal, exciting and action-oriented scenes of the novel must have been considered unsuitable reading for a young girl and were more in line with genre conventions for boys' reading matter. The sentimental style of Uncle Tom's Cabin, on the other hand, marks this novel as a piece of domestic fiction addressing a female audience. The swapping of Anne's reading matter therefore diminishes her independence and 
unruliness as a reader by replacing her somewhat unconventional choice with a text corresponding to conventional genre preferences for her gender.

Even less subtle are the effects of changed literary references on Anne's age profile. Lucy Maud Montgomery's novel is a comingof-age story with some characteristic twists. She certainly accompanies Anne through the final years of her childhood and shows her maturing from an 11-year-old girl to a 16-year-old teenager starting her professional career. But this process of growing up does not run in a straight line. Elements of adult life are shaping Anne's early childhood, since she is forced into adult responsibilities at a very young age. She compensates for this burden by seeking refuge in the realms of imagination and fiction, mixing both into her own rather dismal reality. While she slowly learns how to bridle her imagination, it keeps enriching her life even into adulthood. This blurring of the borders between childhood and adulthood confirms that Anne of Green Gables originally was not intended as a children's book, but as popular reading for a broader audience (McKenzie 140).

Karin Jensen, however, tends to emphasize Anne's childlike qualities more than her mature traits. This disambiguates the character compared with her qualities in the source text. Another intertextual reference illustrates this tendency rather well. When Anne explains to Marilla why she has forgotten a pie in the oven, her excuse is that she had become so entangled in the romantic scenarios of her own imagination that she ignored the time and neglected the pie. She describes how she suddenly felt "an irresistible temptation [...] to imagine [that she] was an enchanted princess shut up in a lonely tower with a handsome knight riding to [her] rescue on a coal-black steed" (133-134). In the translation, Anne is facing a different distraction: "Och allting gick så bra, ända tills jag satte in pajen; då kom jag att tänka på pepparkakshuset och häxan och barnen, som skjutsade henne långt in i ugnen ... Se'n glömde jag pajen" ("And everything went so well, until I put the pie in; then I began to think of the gingerbread house and the witch and the children who pushed her deep into the oven ... Then I forgot about the pie," 185.) One is tempted to declare that this substitution works rather well, because Anne's negligence complies so perfectly with the pretext's specifications: Just as Hansel and Gretel leave the witch to burn in the oven, Anne burns her pie. But then this alteration again shifts our notion of Anne's reading habits. By making her refer to a fairy tale by the brothers Grimm rather than to clichés from popular romance fiction, the Swedish translation portrays her as far more childlike than the 
English source text. Besides, Karin Jensen again prevents Anne from imagining herself into her own fantasy scenario. The vivid images of the fairy tale momentarily push themselves into the foreground of Anne's mind, but do not swallow her.

This focus on Anne's childlike qualities corresponds to a general tendency of Jensen's translation, which is also reflected in a number of substantial abridgements, most of which occur in the second half of the novel. This means that the readers get to spend more time with Anne, the young girl, than with Anne, the teenager and young academic. The cuts in the novel range from single phrases to several pages of text, without a clearly recognizable general agenda. The chapters most affected are chapter 21, which has lost the school's farewell from Mr. Phillips and Anne's criticism of the trial sermons at the church; chapter 25, which sends Matthew directly to Rachel Lynde when he decides to buy Anne a new dress; and chapter 26, the "Story Club" chapter, where only half of the chapter's original content is preserved. Altogether these omissions appear rather arbitrary and seem to be lacking a common motivation. The first half of the novel probably escaped major cuts because it was considered more important than the rest. What is astonishing is not so much that Jensen shortens the text - which was customary in any translation of children's literature at her time. What is far more astonishing is that nothing has ever been done to revoke these changes and present an alternative translation that fills the gaps left by the first Swedish edition, tones down the added judgmental comments and reinstates the ambiguities of the source text.

\section{Enforced Shortcomings: Other Translations}

For even today, more than 110 years after its first publication, Karin Jensen's translation forms the basis of the Swedish standard edition of Anne of Green Gables. More than just its publishing house has changed, however: In the course of the $20^{\text {th }}$ century, Jensen's text has been revised by Britt G. Hallqvist (in 1955) and by Christina Westman, who was commissioned to overhaul Hallqvist's text in 1991 and later to refresh her own revision for a new edition in 2018. Such a revision might be expected to accomplish some formal polishing, to refresh the diction, syntax, spelling and punctuation of a novel. Indeed, the two revisers have gently modernized the entire text, obliterated archaic commas, replaced outdated phrases and erased obsolete plural verb forms, subjunctive forms and many oldfashioned conjunctions and adverbs. So far, so good. Moreover, one 
might also expect a revising editor to compare a translation to its source text and check at least some obviously awkward passages for possible improvements. The newer editions of Anne of Green Gables, however, show no traces of this. One might speculate that the responsible editors were not given enough time for a more thorough revision and therefore limited their attention to superficial stylistic elements. Be this as it may, the result was that the revised editions have faithfully preserved all of Jensen's profound changes and additions, her abridgements and omissions. Rather than informing the readers about these shortening edits, some prints of Westman's revised text (like the one used for this paper) even announce themselves as "Komplett utgåva" ("complete edition") on their title pages. One may therefore conclude that Anne på Grönkulla has been revised like a genuinely Swedish novel, not as a translation - a rather intriguing finding that proves how firmly this version of the text has anchored itself in Sweden's literary memory. On the other hand, this means that Swedish children have yet to discover the bolder, more rebellious and ambiguous Anne from Montgomery's novel, since the three other Swedish translations veer even further away from their source text.

The most radical of these is Christina Birgander's and Birgitta Hvidberg's adaptation into a simplified Swedish, published in the mid-1970s and originally written as a term paper at Malmö Teacher Training College (Lärarhögskolan). The two editors intended to make the text more accessible for foreign students of the Swedish language and for readers suffering from dyslexia, in accordance with the long tradition of abbreviated editions for young readers (Klingberg 73-80). To adapt the novel to these readers' needs, they have shortened it radically and simplified both its language and plot. The text is reduced almost exclusively to the characters' dialogues, while narrative comments and descriptions are limited to a minimum. Birgander and Hvidberg discard the "Story Club" completely and merge several other chapters, so that only 34 of the original 38 chapters remain. Since they limit the lexicon of their adaptation to frequently used terms, its language appears very simple: the sentences are short and the syntax plain. While this edition manifests genuine commitment to Montgomery's creation, very little word substance remains of her source text. This translation and adaptation is an enlightening experiment that scrutinizes the novel for its key characteristics and poetics. By reducing these core qualities of Anne of Green Gables so drastically, the two editors have tested if the novel can work independently of its established narrative and stylistic presentation. 
Since their version has never been re-issued, this does not appear to be the case. One may only speculate about the reasons for its lack of success. What seems likely, though, is that intricate interactions of experience and language are so essential to Anne of Green Gables in general and to Anne's character in particular that she loses her identity when all her big words and all descriptions of her island vanish from the story. While the simplified text may still assert her love of language and nature, what actually remains of this love is but a vague proposition.

The remaining two versions of Anne of Green Gables, on the other hand, manage to render Montgomery's style rather faithfully. ${ }^{8} \mathrm{Ne}-$ vertheless, despite the undeniable competence and merits of their translators, Aslög Davidson and Margareta Sjögren-Olsson, Karin Jensen's version is still preferable, since their translations abbreviate the novel even more radically than hers does. Unlike Jensen, Davidson and Sjögren-Olsson (or their publishers) have omitted not merely sentences and paragraphs, but entire chapters in their translations. The remaining parts have also been abbreviated severely, ${ }^{9}$ primarily the descriptive passages and those referring to the characters' thoughts and emotions. Davidson omits 11 chapters, and Sjögren-Olsson as many as 13 complete chapters; the bulk of these omissions occurs in the second half of the novel, which again emphasizes the early parts of the narrative and thus Anne's childhood experiences at the expense of her teenage years. ${ }^{10}$ The essential Swedish Anne, it appears, is the imaginative girl who stumbles into some risky and funny situations, not so much the creative teenager and the responsible college student of the later chapters. The omissions therefore accord with a strain of criticism that generally laments Anne's maturation (Thomas): They wipe out as much as possible of the woman in favour of the young girl. What underlines the programmatic tendency of these cuts is the fact that both Davidson and SjögrenOlsson only ever translated the first two volumes of Montgomery's Anne series, Anne of Green Gables and Anne of Avonlea.

One effect of the drastic cuts and changes in these two translations is that Anne's maturation from child to young woman appears as a very sudden event in the first volume of the series, since so many episodes central to her development have been left out. Moreover, the majority of Montgomery's atmospheric passages are also eliminated: her descriptions of the weather, of rooms, of promenades and landscapes - in short, everything that does not contribute directly to advancing the plot. Besides, the multifocal approach so characteristic of Montgomery's storytelling is toned down. In her polyphonic narrati- 
ve presentation, she integrates the points of view and even the voices of different characters into that of the narrator. Many such passages have been omitted in Davidson's and Sjögren-Olsson's translations, which thus submit the text to the control of a central narrative authority. Davidson, for example $(81,77)$, skips the passages that reveal Marilla's opinions about Anne and Rachel Lynde (59-60, 56), while Sjögren-Olsson (113) rephrases the account of Anne's visit to the Barrys' after her disastrous tea party with Diana (108-109). In her version, the narration does not give reliable insights into Mrs. Barry's thoughts anymore, but merely describes the strict and stiff impression she leaves on Anne - while the narrator in the English source text explicitly seeks to justify Mrs. Barry's behaviour: "To do her justice, she really believed Anne had made Diana drunk out of sheer malice prepense, and she was honestly anxious to preserve her little daughter from the contamination of further intimacy with such a child" (108-109). Elsewhere Sjögren-Olsson also changes the narrative voice presenting the story. The voice of the narrator in Montgomery's own text shows traces of figuralization (Schmid 120). It absorbs some of Anne's and Diana's utterances, for example when the two girls are discussing the "perfectly elegant tea" they have before the Debating Club concert or the "thrills" that the concert program exerts on them. Sjögren-Olsson (125-126) levels this polyphony and integrates such traces of direct speech into the unisonous account of the narrator (125-126).

An average reader will probably not notice these changes, and still experience the text as coherent and complete. But since all episodes constitute a fabric of interdependent narrative components, any abridgement may start unravelling the texture of the story. A good example of this is the character exposition of Marilla Cuthbert. Montgomery introduces her long before Anne and thus establishes her as a second protagonist of the novel, as one who undergoes similarly dramatic changes as Anne herself. Sjögren-Olsson, however, eliminates the entire first chapter and thus deprives her audience of the reading experience of meeting Marilla before Anne and developing an understanding of her point of view before the younger protagonist enters the narrative stage.

The effect of these omissions on the narrative structure becomes increasingly apparent towards the end of the novel, when Anne reminisces about her childhood experiences together with Marilla and Diana. The source text presents her memories in stretto-like summaries that bundle together earlier events from a different point of view. But since unmentioned events cannot be retold, the final chapters of the curtailed translations appear far less intense. 
To judge these major abridgements, it is not sufficient to speculate about ideological motivations behind them or accuse the translators of censorship; we have to take into account the publishing conditions and the material appearance of the abbreviated editions as well. All major Swedish translations of Anne of Green Gables were published within series of books for young readers, and all these series had certain standard restrictions regarding the page count. The most liberal among them appears to have been C.W.K. Gleerups ungdomsböcker (C.W.K. Gleerup's Young Adult Books), the series for which Karin Jensen provided the translation. Judging from other books published here at the time, this series provided a rather generous editorial environment and permitted anything between 60 and 550 pages. Therefore a text comprising around 330 pages like Anne of Green Gables would not have caused any major problems or prompted compulsory abbreviations, although it slightly exceeded the average of 200250 pages. Nonetheless publisher Agne Gleerup asked Karin Jensen to make a couple of abbreviations, since he considered anglophone youth novels in general too long for Swedish readers, but possibly also because he wanted the novel to reach a younger audience than the original United States edition, which addressed readers of all ages (Warnqvist, "Don't be too upset" 8; "I experienced a light" 232; "Anne på Grönkulla" 214). Seved Ribbing supported this request by providing Gleerup with detailed suggestions for possible cuts, which Gleerup forwarded to Jensen. As Warnqvist has reconstructed from later comments in Gleerup's letters to Jensen ("Don't be too upset" 10-11), Ribbing also came up with the final translation for the name of the Cuthberts' farm and therefore of the entire novel Anne of Green Gables. Unfortunately his notes along with Karin Jensen's replies to Gleerup have been lost, which prevents us from reconstructing how exactly Jensen let these notes guide her translatorial decisions to omit some passages, change others significantly and add additional material or comments from time to time (Warnqvist, "I experienced a light" 232). All in all her interventions still appear relatively moderate compared with those of the other two translators, who faced far stricter limitations: Margareta Sjögren-Olsson had to fit the text into the publisher Lindblad's series De klassiska ungdomsböckerna (The Classic Young Adult Books), with a default limit of 150-190 pages; Aslög Davidson translated for B. Wahlströms ungdomsböcker (B. Wahlström's Young Adult Books), a series of popular fiction for young adult readers, issued by a publishing house that focused on affordable books for the mass-market (Warnqvist, "Anne på Grönkulla” 219-220; Andræ). B. Wahlströms ungdomsböcker generally allowed for a maximum of 160 pages per volume; longer texts 
like Louisa May Alcott's Little Women or Anne of Green Gables were sold as double volumes at double the price. Both the Wahlström and Lindblad editions clearly went below the page limit of their respective series, with Davidson's text comprising only 251 pages and Sjögren-Olsson's a mere 158.

In both cases it is obviously not the translators alone who were responsible for shortening the novel; their interventions were prompted, possibly even guided, by their publishers' and editors' demands, like in Jensen's case. While the material restrictions of the book series provided an outer framework into which the text had to be fitted, the decision about exactly which chapters and passages to omit still provides important insights into the publishing houses' concept of their potential readers, and their strategies for moulding Anne of Green Gables towards this audience. Their interventions suggest that they aimed the novel at a narrower, younger group of readers than the publisher of the source text, since they focused less on Anne as a maturing teenager than on the little orphan girl - a tendency that ties in with the changes we have already encountered in Karin Jensen's first Swedish translation.

\section{Book or Folklore: Words that Matter}

Although the general popularity of Anne of Green Gables in Sweden certainly can be attributed to the book's original substance, some characteristic changes in Karin Jensen's translation have contributed to Anne's enormous success on the Swedish book market and shaped her character profile for generations of Swedish readers. Jensen adapts details of Montgomery's novel to its Swedish target culture, which makes its fictional world more familiar and therefore easier to access and comprehend for Swedish readers. Her added elements of burlesque humor might appear predominantly entertaining, but like the judgmental comment put into Miss Stacy's mouth, they serve to discipline the character of Anne and limit her scope of action by raising additional doubts about whether her flights of fancy and often bold actions are appropriate for a young girl. Jensen's added emphasis on elements of female interest and the substituted intertexts, which turn Anne into a less omnivorous and more conventionally female young reader, support this tendency to narrow down Anne's transgressive disposition and disambiguate her stance and status between girlhood and womanhood, imagination and reality.

These transformations reflect the conditions of a literary system that values children's books for their educational effects rather than 
for their aesthetic qualities. This does not necessarily make the translation an inferior text - much depends on what its audience expects of it, and whether the translation fulfills these expectations (Chesterman 205-208). While many distinct features of Jensen's translation were unremarkable and went unnoticed by contemporary readers, they deviate from present-day translation standards. Many Swedish readers of younger generations, who have have read both the translation and its English source text, are irritated by the changes (Warnqvist, Besläktade själar 86-89, 54). Nevertheless, Jensen's translation generally receives high praise for its engaging and poetic style (Warnqvist, Besläktade själar 74, 126, 171, 202, 264). Despite some inconsistencies, the qualities of her work are undeniable; she has created a canonical text to which many Swedish readers are so deeply attached that any changes to the translation might offend them: a classic in its own right.

Additionally one might argue that it is changes like these, adjusting Anne of Green Gables to the norms and values of a particular target culture, that have been decisive for her global success (Gammel et al. 167). For the Swedish Anne, we could speculate about how her specific national profile might have struck a chord with post-war Swedish readers, who encountered similar children in the texts of Astrid Lindgren. Reducing Anne's ambiguities favours an image of her as an imaginative, but initially uncultivated girl, and emphasizes those strands of her story that focus on the emancipation and empowerment of an underprivileged child gaining agency. This might have granted her resonance in Sweden, even though the gender concepts stressed by Jensen's changes appear outdated compared with those represented by many of Lindgren's stories, from Pippi Longstocking to Ronia, the Robber's Daughter.

Just as gender concepts change over time, so do translation standards (Joosen) and the norms and principles of the literary system. During the $20^{\text {th }}$ and $21^{\text {st }}$ centuries Western children's literature has become used to openly embracing complexity and ambiguities in texts for young readers. Translators have also developed greater faith in children's ability to handle new concepts in recent decades (Lathey, "The Translation of Literature for Children" 203) instead of shielding them against foreign elements (Epstein, "The Conservative Era" 76; Bell 3). Confronting readers with the unfamiliar and challenging their understanding are key functions of translations in general (Venuti). These have also been recognized as important tasks of children's literature, since encounters with the foreign can nurture cross-cultural understanding, respect, and learning about our com- 
plex world (Klingberg 17; Nikolajeva, "Translations" 404, Stolze 209; Yamazaki 57-60) and help children to construct a cultural identity (O'Sullivan, "Children's Literature" 290).

In the light of these developments and changing standards it is intriguing that the text of Anne of Green Gables currently available on the Swedish book market obscures so much of this novel's literary potential that would resonate very well with a present-day audience. While the sharpened profile of Karin Jensen's Anne has helped to establish and anchor her character in Sweden's literary memory, a more complex image of her might strengthen the dual address of a novel that has already captivated an audience of children as well as adults in the country (Warnqvist, Besläktade själar 60, 97, 101, 160).

It remains to be seen if and how Anne of Green Gables will remain present in Sweden's popular reading culture: as a distinct work that gains its allure from its characteristic narrative presentation - or as a piece of written folklore, which Emer O'Sullivan has described as the predominant transmission mode of children's classics ("Does Pinoccio have an Italian Passport?" 159-162). When a text enters the realm of written folklore, it loses its character as a distinct work of art with a specific literary form and wording. Instead, it turns into a dynamic compilation of material undergoing seemingly endless transformations. This results in a series of versions linked only by a set of key elements: a mere frame and skeleton to be filled with changing details in ever new adaptations. The Swedish translators who have narrowed down the literary profile of Anne of Green Gables might have paved the path towards such an expansion into an open cosmos of creative retellings, since the loss of complexity enhances Anne's remaining central features. However, a retranslation that unearths and embraces the hitherto dampened complexity of the source text could revivify the Swedish reception of Anne of Green Gables in a different way: as a book worth reading and loving, with words that matter.

Biographical information: Cornelia Rémi currently serves as Acting Chair of German Literature at Julius-Maximilians-Universität Würzburg after previous appointments at the universities of Munich and Tübingen. She has written book-length studies on early modern spiritual poetry and on functions of withheld or inaccessible information in nineteenth-century prose. Her research focuses on artistic strategies for coping with uncertainty and developing a concept of self, be it in seventeenth-century manuscripts and broadsheets, in voluminous novels of the Victorian era, in non-fiction books and poems for children or in contemporary picturebooks. In recent talks she has explored the poetics of James Krüss, Tonke Dragt, and Astrid Lindgren's war diaries. 


\section{Works Cited}

Aixelá, Javier Franco. "Culture-Specific Items in Translation." Translation, Power, Subversion, edited by Román Álvarez and M. CarmenÁfrica Vidal, Clevedon, Multilingual Matters, 1996, pp. 52-78.

Allard, Danièle. "Hanako Muraoka's Famous and Truncated Translation of Anne of Green Gables: Some Lingering Questions." Storm and Dissonance: L.M. Montgomery and Conflict, edited by Jean Mitchell, Newcastle, Cambridge Scholars Publishing, 2008, pp. 344-362.

Andræ, Marika. Rött eller grönt? Flicka blir kvinna och pojke blir man i B. Wahlströms ungdomsböcker 1914-1944 [Red or green? Girl becomes woman and boy becomes man in B. Wahlströms youth books 1914-1944]. Stockholm, B. Wahlströms, 2001.

Bar-Hillel, Gili. "Bridging the Gastronomic Divide in Translating Children's Literature." Feast or Famine? Food and Children's Literature, edited by Bridget Carrington and Jennifer Harding. Newcastle upon Tyne, Cambridge Scholars Publishing, 2014, pp. 206-212.

Bassnett, Susan. "The Translator as Cross-Cultural Mediator." The Oxford Handbook of Translation Studies, edited by Kirsten Malmkjær and Kevin Windle, Oxford, Oxford University Press, 2011, pp. 94-107.

Bell, Anthea. "Translator's Notebook: The Naming of Names." Signal, vol. 46, 1985, pp. 3-11.

Bertills, Yvonne. Beyond Identification: Proper Names in Children's Literature. Åbo, Åbo Akademi University Press, 2003.

Brewster, Hilary. "Wizard in Translation: Linguistic and Cultural Concerns in Harry Potter." Internationalism in Children's Series, edited by Karen Sands-O'Connor and Marietta A. Frank, Basingstone, Palgrave Macmillan, 2014, pp. 159-173.

Browning, Robert. The Complete Works of Robert Browning With Variant Readings $\mathcal{E}$ Annotations, edited by Roma A. King, Jr. et al., vol. V, Athens, Ohio University Press, 1981.

Byron, George Gordon. The Complete Poetical Works, edited by Jerome J. McGann, vol. 2: Childe Harold's Pilgrimage, Oxford, Clarendon Press, 1980.

Chesterman, Andrew. "Causes, Translations, Effects." Target: International Journal of Translation Studies, vol. 10, no. 2, 1998, pp. 201-230.

Chiaro, Delia, and Linda Rossato. "Food and Translation, Translation and Food." The Translator, vol. 21, no. 3, 2015, pp. 237-243, doi. org/10.1080/13556509.2015.1110934. 
van Coillie, Jan. "Character Names in Translation: A Functional Approach." Children's Literature in Translation: Challenges and Strategies, edited by Jan van Coillie and Walter P. Verschueren, London and New York, Routledge, 2006, pp. 123-139.

Davies, Eirlys E. "A Goblin or a Dirty Nose? The Treatment of Culture-Specific References in Translations of the Harry Potter Books." The Translator, vol. 9, no. 1, 2003, pp. 65-100, doi.org/10.1080/13556 $\underline{509.2003 .10799146 .}$.

Death, Sarah. "Pippi Långstrump and Anne of Green Gables: Tribute and Subversion." Proceedings of the 10th Biennial Conference of the British Association of Scandinavian Studies, held at the University of Surrey, Department of Linguistics and International Studies, edited by Gunilla Anderman and Christine Banér, Guildford, University of Surrey, 1995, pp. 212-221.

Desmet, Mieke K. T. “Intertextuality/Intervisuality in Translation: The Jolly Postman's Intercultural Journey from Britain to the Netherlands." Children's Literature in Education, vol. 32, no. 1, 2001, pp. 3143, doi.org/10.1023/A:1005214004763.

Doody Jones, Mary E. "Breaking the Silence: Music and Elocution." Lucy Maud Montgomery. The Annotated Anne of Green Gables, edited by Wendy E. Barry et al., New York/Oxford, Oxford University Press, 1997, pp. 452-457.

Doody, Margaret Anne, and Wendy E. Barry. "Literary Allusion and Quotation in Anne of Green Gables." Lucy Maud Montgomery. The Annotated Anne of Green Gables, edited by Wendy E. Barry et al., New York/Oxford, Oxford University Press, 1997, pp. 457-462.

Epstein, B. J. “The Conservative Era: a Case Study of Historical Comparisons of Translations of Children's Literature from English to Swedish." Literary Translation: Redrawing the Boundaries, edited by Boase-Beier et al., London, Palgrave Macmillan, 2014, pp. 64-78.

---. "In Name Only? Translating Names in Children's Literature." Northern Lights: Translation in the Nordic Countries, edited by B. J. Epstein, Oxford, Peter Lang, 2009, pp. 191-209.

---. Translating Expressive Language in Children's Literature: Problems and Solutions. Bern, Peter Lang, 2012.

Ewers, Hans-Heino. Fundamental Concepts of Children's Literature Research: Literary and Sociological Approaches. Translated by William J. McCann, New York/London, Routledge, 2009. 
Fernandes, Lincoln. “Translation of Names in Children's Fantasy Literature: Bringing the Young Reader into Play." New Voices in Translation Studies, vol. 2, 2006, pp. 44-57.

Gammel, Irene et al. "An Enchanting Girl: International Portraits of Anne's Cultural Transfer." Anne's World: A New Century of Anne of Green Gables, edited by Irene Gammel and Benjamin Lefebvre, Toronto, University of Toronto Press, 2010, pp. 166-191.

Garavini, Melissa. "The Adaptation of 'Adaptation' in Translation Studies Focusing on Children's Literature." Where is Adaptation? Mapping Cultures, Texts, and Contexts, edited by Casie Hermansson and Janet Zepernick, Amsterdam, John Benjamins, 2018, pp.365-380.

House, Juliane. Translation as Communication across Languages and Cultures. Abingdon/New York, Routledge, 2016.

Joosen, Vanessa. "From Breaktime to Postcards: How Aidan Chambers Goes (Or Does Not Go) Dutch." Children's Literature in Translation: Challenges and Strategies, edited by Jan van Coillie and Walter P. Verschueren, London/New York, Routledge, 2006, pp. 61-78.

Karr, Clarence. "Addicted to Reading: L. M. Montgomery and the Value of Reading." Canadian Children's Literature, vol. 113-114, 2004, pp. 17-33.

Klingberg, Göte. Children's Fiction in the Hands of the Translators, Lund, Gleerup, 1986.

Lathey, Gillian. Translating Children's Literature, London/New York, Routledge, 2016.

---. "The Translation of Literature for Children." Routledge Encylopedia of Translation Studies, edited by Mona Baker and Gabriela Saldanha, 3rd ed., Abingdon/New York, Routledge, 2019, pp. 60-65.

---. "The Translation of Literature for Children." The Oxford Handbook of Translation Studies, edited by Kirsten Malmkjær and Kevin Windle, Oxford, Oxford University Press, 2011, pp. 198-213.

---. "The Travels of Harry: International Marketing and the Translation of J. K. Rowling's Harry Potter Books." The Lion \& the Unicorn, vol. 29, no. 2, 2005, pp. 141-151, doi.org/10.1353/uni.2005.0028.

McKenzie, Andrea. "Patterns, Power, and Paradox: International Book Covers of Anne of Green Gables across a Century." Textual Transformations in Children's Literature: Adaptations, Translations, Reconsiderations, edited by Benjamin Lefebvre, New York, Routledge, 2013, pp. 127-154. 
Montgomery, Lucy Maud. Anne of Green Gables: Authoritative Text, Backgrounds, Criticism, edited by Mary Henley Rubio and Elizabeth Waterston, New York, Norton, 2007.

---. Anne på Grönkulla [Anne of Green Gables]. Translated by Karin Jensen, Lund, C.W.K. Gleerups, 1909.

---. Anne på Grönkulla [Anne of Green Gables]. Translated by Karin Lidforss Jensen, edited by Britt G. Hallquist, 14th ed., Malmö, C.W.K. Gleerups, 1955.

---. Anne på Grönkulla [Anne of Green Gables]. Translated by Karin Lidforss Jensen, edited by Christina Birgander and Birgitta Hvidberg, Lund, LiberLäromedel, 1976.

---. Anne på Grönkulla [Anne of Green Gables]. Translated by Karin Lidforss Jensen, edited by Christina Westman, 3rd ed., Stockholm, Klassikerförlaget, 1991.

---. Anne på Grönkulla. [Anne of Green Gables]. Translated by Margareta Sjögren-Olsson, Stockholm, B. Wahlströms, 1962.

---. Anne på Gröntorpa: Berättelse för flickor [Anne of Green Gables: story for girls]. Translated by Aslög Davidson, Stockholm, B. Wahlströms, 1941.

Nikolajeva, Maria. Children's Literature Comes of Age: Towards A New Aesthetic, New York, Garland Publishing, 1996.

---. "Translations and Crosscultural Reception." Handbook of Research on Children's and Young Adult Literature, edited by Shelby Wolf et al., New York, Routledge, 2011, pp. 404-416.

Nord, Christiane: "Proper Names in Translations for Children: Alice in Wonderland as a Case in Point." Meta: Journal des traducteurs, vol. 48, no. 1-2, 2003, pp. 182-196.

Oittinen, Riitta. Translating for Children. New York, Garland, 2000.

Olausson, Rune. Bengt Anderberg. Malmö, Bengt Forsbergs, 1967.

O'Sullivan, Emer. "Children's Literature." Imagology: The Cultural Construction and Literary Representation of National Characters: A Critical Survey, edited by Manfred Beller and Joep Leerssen, Amsterdam/ New York, Rodopi, 2007, pp. 290-294.

---. "Children's Literature and Translation Studies." The Routledge Handbook of Translation Studies, edited by Carmen Millán and Francesca Bartrina, London/New York, Routledge, 2013, pp. 451-463. 
---. "Does Pinoccio have an Italian Passport? What is Specifically National and what is International about Classics of Children's Literature." The Translation of Children's Literature: A Reader, edited by Gillian Lathey, Clevedon, Multilingual Matters, 2006, pp. 146-162.

---. Kinderliterarische Komparatistik. Heidelberg, Winter, 2000.

---. "Narratology Meets Translation Studies, or, The Voice of the Translator in Children's Literature." Meta: Journal des traducteurs, vol. 48, no. 1-2, 2003, pp. 197-207.

Rémi, Cornelia. "Interactions with Poetry: Metapoetic Games with Anne in Astrid Lindgren's Madicken." 100 years of Anne with an ' $e$ ': The Centennial Study of Anne of Green Gables, edited by Holly Blackford, Calgary, University of Calgary Press, 2009, pp. 165-190.

Salah, Christiana R. "A Ministry of Plum Puffs: Cooking as a Path to Spiritual Maturity in L. M. Montgomery's Anne Books." 100 Years of Anne with an 'e': The Centennial Study of Anne of Green Gables, edited by Holly Blackford, Calgary, University of Calgary Press, 2009, pp. 193-209.

Schleiermacher, Friedrich Daniel Ernst. "Über die verschiedenen Methoden des Übersetzens." Kritische Gesamtausgabe, vol. 11: Akademievorträge, edited by Martin Rößler and Lars Emersleben, Berlin/ New York, de Gruyter, 2002, pp. 65-93.

Schmid, Wolf. Narratology: An Introduction. Translated by Alexander Starritt, Berlin/New York, de Gruyter, 2010.

Seifert, Martina. "Conflicting Images: Anne of Green Gables in Germany." Storm and Dissonance. L.M. Montgomery and Conflict, edited by Jean Mitchell, Newcastle, Cambridge Scholars Publishing, 2008, pp. 328-343.

Shavit, Zohar. Poetics of Children's Literature. Athens/London, The University of Georgia Press, 1986.

---. "Translation of Children's Literature as a Function of its Position in the Literary Polysystem." Poetics Today, vol. 2, no. 4, 1981, pp. 171-179.

Stolt, Birgit. "How Emil Becomes Michel: On the Translation of Children's Books." The Translation of Children's Literature: A Reader, edited by Gillian Lathey. Clevedon, Multilingual Matters, 2006, pp. 67-83.

Stolze, Radegundis. "Translating for Children - World View or Pedagogics." Meta: Journal des traducteurs, vol. 48, no. 1-2, 2003, pp. 208-221. 
Surmatz, Astrid. Pippi Långstrump als Paradigma: Die deutsche Rezeption Astrid Lindgrens und ihr internationaler Kontext. Tübingen/Basel, Francke, 2005.

Szymańska, Izabela. "Ever-Green Gables: On Modernized Retranslations of Children's Classics." Old Masters in New Interpretations: Readings in Literature and Visual Culture, edited by Anna Kwiatkowska, Newcastle upon Tyne, Cambridge Scholars Publishing, 2016, pp. 113-131.

Tabbert, Reinbert. "Approaches to the Translation of Children's Literature: A Review of Critical Studies since 1960." Target: International Journal of Translation Studies, vol. 14, 2002, pp. 303-351.

Thomas, Gillian. "The Decline of Anne: Matron vs. Child." Such a Simple Little Tale: Critical Responses to L. M. Montgomery's Anne of Green Gables, edited by Mavis Reimer, Metuchen/London, The Children's Literature Association and The Scarecrow Press, 1992, pp. 23-28.

Thomson-Wohlgemuth, Gaby. Translation under State Control: Books for Young People in the German Democratic Republic. London, Routledge, 2009.

Venuti, Lawrence. "Translation as Cultural Politics: Regimes of Domestication in English." Textual Practice, vol. 7, no. 2, 1993, pp. 208-223.

Warnqvist, Åsa. “Anne på Grönkulla - 'en af de nöjsammaste bekantskaper man kan göra': Utgivning och mottagande av L. M. Montgomerys verk i Sverige" [Anne of Green Gables - 'one of the most pleasant acquaintances one can make': the publication and reception of L.M. Montgomery's works in Sweden]. I litteraturens underland: festskrift till Boel Westin [In the wonderland of literature: festschrift to Boel Westin], edited by Maria Andersson et al., Stockholm, Makadam, 2011, pp. 212-229.

---, editor. Besläktade själar: Läsupplevelser av Anne på Grönkulla [Kindred spirits: reading experiences of Anne of Green Gables]. Lund, BTJ förlag, 2009.

---. "'Don't be too upset with your unchivalrous publisher': Translator-Publisher Interactions in the Swedish Translations of L.M. Montgomery's Anne and Emily Books." Barnboken: Journal of Children's Literature Research, vol. 42, 2019, doi.org/10.14811/clr.v42i0.449.

---. "'I experienced a light that became a part of me': reading Anne of Green Gables in Sweden." Anne around the World: L. M. Montgomery 
and Her Classic, edited by Jane Ledwell and Jean Mitchell, Montreal/ Kingston, McGill-Queen's University Press, 2013, pp. 228-242.

---. “'Under körsbärsträdet sitter Ann': dialogen med L. M. Montgomery i Astrid Lindgrens verk" ['Under the cherry tree Ann sits': the dialogue with L.M. Montgomery in Astrid Lindgren's works]. Nya läsningar av Astrid Lindgren [New readings of Astrid Lindgren], edited by Helene Ehriander and Martin Hellström. Stockholm, Liber, 2015, pp. 103-121.

Wennerberg, Gunnar. Samlade Skrifter [Collected works]. Vol. 2: Gluntarne, Stockholm, Seligmann, 1882.

Wilmshurst, Rea. "L. M. Montgomery's Use of Quotations and Allusions in the 'Anne' books." Canadian Children's Literature, vol. 56, 1989, pp. 15-45.

Woster, Emily. “Old Years and Old Books: Montgomery's Ontario Reading and Self-Fashioning." L. M. Montgomery's Rainbow Valleys: The Ontario Years, 1911-1942, edited by Rita Bode and Lesley D. Clement, Montreal/Kingston, McGill-Queen's University Press, 2015, pp. 151-165.

Yamazaki, Akiko. "Why Change Names? On the Translation of Children's Books." Children's Literature in Education, vol. 33, no. 1, 2002, pp. 53-62, doi.org/10.1023/A:1014467726005.

Åhmansson, Gabriella. “'Mayflowers grow in Sweden, too': L.M. Montgomery, Astrid Lindgren and the Swedish Literary Consciousness." Harvesting Thistles: The Textual Garden of L.M. Montgomery. Essays on Her Novels and Journals, edited by Mary Henley Rubio, Guelph, Canadian Children's Press, 1994, pp. 14-22.

\section{Notes}

1 I am indebted to Åsa Warnqvist for providing me with several Swedish editions of Anne of Green Gables that would have been unavailable for me without her help. The municipal library of Pedersöre, Finland supported my work by agreeing to send me their old copy of the Sjögren-Olsson translation in exchange for a more recent edition. Their friendly approval of my request might have been accelerated by my pointing out that the text of their copy was missing more than one third of the original chapters. I also thank Örjan Blix, probably one of the most attentive readers Montgomery has ever found in Sweden (Warnqvist, Besläktade själar 79-91), for our intense discussions about the Swedish translations of Anne of Green Gables. 
2 Not only girls were fascinated by her books: Anne of Green Gables was liked by boys as well. Author Bengt Anderberg remembers devouring the book as a 10-year old: "I must confess that I was deeply fascinated by Anne på Grönkulla, which I read around 1930, parallel to [August Strindberg's novel] The Red Room" (Olausson 121).

3 Szymańska is examining the different Polish translations of Anne of Green Gables as a "translation series." This concept, suggested by Polish scholar Edward Balcerzan, describes multiple translations of one text into the same target language and highlights the systematic nature of emerging reinterpretations of a single work (Szymańska 113-116). Due to the number of Swedish translations of Anne of Green Gables, studying them more profoundly as such a translation series might be a rewarding approach.

4 Unless mentioned otherwise, all references are to Rubio's and Waterston's critical Norton edition and to Jensen's first translation respectively.

5 Later on in the text, the Swedish name creations even get mixed up: Jensen translates the combination "Willowmere and Victoria Island" (201) with terms that she had earlier $(117,314)$ introduced as translations for what Montgomery calls "Violet Vale" (88) and "Idlewild" (232): "Violernas dal och Näktergalsro" (270).

6 Take for example one of the first dresses Anne receives at Green Gables: The "snuffy coloured gingham" (67) turns into a "snuffy coloured linen fabric with yellow dots" ("snusfärgat linne med gula prickar," 87). She also describes curtain patterns in more detail than Montgomery does: Where the narrator in the original texts describes the curtains in Anne's room as "of pale green art muslin" (212), Jensen writes about curtains "of the thinnest muslin, white base checkered with green" ("av tunnaste musslin, vit botten med gröna rutor," 286).

7 Cf. 15/12, 17/15, 19/17, 31/35, 33/37, 53/67, 65/84, 67/87, 79/103, $104 / 140,114 / 156,188 / 252$ (first page number referring to Montgomery's original, second one to Jensen's translation).

8 With only some inconsequent or conspicuously sloppy passages. Davidson, for example (189-190), omits chapter 23 ("Anne comes to grief in an affair of honour"), but inserts Anne's description of Miss Stacy's teaching method from that chapter in the following one $(153,155)$, which results in two strangely similar mentions of physical education lessons within the same conversation. Davidson also translates two different kind of apples ("Red Sweetings," 103, and "strawberry apples," 112) as "rosenhäger" $(129,143)$, which disturbs the logic of Anne's reasoning: If Anne and Diana pick such apples in the Green Gables orchard, it seems rather implausible for Anne to allocate them exclusively to the Blythe orchard later on.

9 The following passage (97) may serve to illustrate the extent of these abbreviations. All the words set in italics have vanished in SjögrenOlssons's target text (103-104): “Mr. Phillips's brief reforming energy was over; he didn't want the bother of punishing a dozen pupils; but it was necessary to do something to save his word, so he looked about for a scapegoat and found it in Anne, who had dropped into her seat, gasping for breath, with a forgotten lily wreath hanging askew over one ear and giving her a 
particularly rakish and disheveled appearance. 'Anne Shirley, since you seem to be so fond of the boys' company we shall indulge your taste for it this afternoon,' he said sarcastically. 'Take those flowers out of your hair and sit with Gilbert Blythe.' The other boys snickered. Diana, turning pale with pity, plucked the wreath from Anne's hair and squeezed her hand. Anne stared at the master as if turned to stone. 'Did you hear what I said, Anne?' queried Mr. Phillips sternly. 'Yes, sir,' said Anne slowly 'but I didn't suppose you really meant it.' 'I assure you I did'--still with the sarcastic inflection which all the children, and Anne especially, hated. It flicked on the raw. 'Obey me at once.' For a moment Anne looked as if she meant to disobey. Then, realizing that there was no help for it, she rose haughtily, stepped across the aisle, sat down beside Gilbert Blythe, and buried her face in her arms on the desk. Ruby Gillis, who got a glimpse of it as it went down, told the others going home from school that she'd 'acksually never seen anything like it--it was so white, with awful little red spots in it.' To Anne, this was as the end of all things. It was bad enough to be singled out for punishment from among a dozen equally guilty ones; it was worse still to be sent to sit with a boy, but that that boy should be Gilbert Blythe was heaping insult on injury to a degree utterly unbearable."

10 Davidson eliminates chapters 13-14, 20, 23, 26-29, 31, 33-34, Sjögren-Olsson chapters 1, 20-24, 26-29, 31, 33-34. 